\title{
Science Teachers' Assessment and Grading Practices in Swedish Upper Secondary Schools
}

\author{
Maria del Carmen Gómez (Corresponding author) \\ School of Science Education, Malmö University \\ Valdemarsväg 3, 22474 Lund, Sweden \\ E-mail: Maricarmen7879@gmail.com
}

Anders Jakobsson

School of Science Education, Malmö University

Hjälmarsväg 10 Malmö 20506 Malmö Sweden

E-mail: Anders.jakobsson@mah.se

Received: January 16, 2015 Accepted: January 29, 2015 Published: February 15, 2015

doi:10.5296/jet.v2i2.7107 URL: http://dx.doi.org/10.5296/jet.v2i2.7107

\begin{abstract}
This study examines science teachers' assessment and grading practices as well as student participation in the assessment process in the upper secondary school. The teachers were asked about how and when they assess students and what was crucial when grading students. We asked when they considered students to have developed the following knowledge criteria: aptitude for critical thinking, analytical and practical skills and how they assessed students regarding these skills. We report overall evidence-based assessment practices from the teachers' comments in face-to-face interviews. Teachers' comments are closely aligned and associated with long-established beliefs. The assessment and grading practices were found to be at odds with modern perspectives of assessment as well as its role in learning.
\end{abstract}

Keywords: Grades; Assessment Practices; Science Education; Upper Secondary School; Knowledge

\section{Introduction}

Our study is based on issues related to developments in Swedish teachers' assessment practices following school reforms in 1994 and the revised curriculum of 2011 (SOU, 2008, p. 27). In these documents, the epistemology of concepts on knowledge, understanding, confidence in the subject matter, aptitude for critical thinking and students' participation in their own assessment have been particularly emphasised. Changes to the national curriculum in Sweden and recent research in western countries suggest that assessment and grading both 
require new approaches to measuring and evaluating students' learning. Our study seeks to determine how these issues relate in a Swedish context and is one of several reporting the findings of a larger research project that aims to examine teachers' assessment practices in upper-secondary science in Sweden.

International and Swedish research literature shows that teachers' assessment practices have yet to be examined (McMillan, Myran, \& Workman, 2002). Further, Johnston, Afflerbach and Weiss (1993) noted the lack of research in this area and, in later studies, McMillan et al. (2002) discusses the same problem. In the Swedish context it is important to study how teachers assess and grade students as we have changed the curriculum and we need to know how teachers take into account the new guidelines on assessment. The prominent assessment research, both international and from a Swedish perspective, has above all focussed on compulsory schools (e.g., Brookhart, 1994, 1997, 2004; Brown, 2004; Cizek, Fitzgerald, \& Rachor, 1995, 1996; Klapp Lekholm \& Cliffordson, 2009; Martínez, Stecher, \& Borko, 2009; McMillan et al., 2002; McMillan \& Nash, 2000) or on the effects of classroom assessments (e.g., Alkharusi, 2008; Harlen \& Crick, 2003). Teachers' literacy as regards assessment has also been reported (e.g., Brookhart, 2011; DeLuka \& Klinger, 2010; Howley, Howley, Henning, Gillam, \& Weade, 2013), as well as students' conceptions of assessment processes (e.g., Andersson, 2000; Brookhart \& Bronowicz, 2003; Brown \& Hirschfeld, 2008). Only few studies highlight factors that influence teachers' assessment practices (e.g., Martínez et al., 2009). Additionally, research exploring how teachers assess student achievement in upper secondary schools within the framework of science education is relatively rare. The current study addresses these issues by examining teachers' own statements about assessment processes. The national curriculum in Sweden prescribes students' participation in assessment; for this reason, we will additionally focus on how and in what ways they are involved. This also implies examining the extent to which teachers use features of formative assessment to serve the social construction of scientific knowledge according to the national curriculum.

\section{The Research on Teachers' Assessment}

The predominant research on compulsory schooling from both international and Swedish perspectives suggests that student assessment is left to individual teachers. Additionally, most research in the area shows that it is not specifically studied or understood (e.g., Brookhart, 1994; James \& Pedder, 2006). However, recent studies indicate that both achievement and non-achievement are taken into account when teachers assign grades (Klapp Lekholm \& Cliffordson, 2008; 2009). For example, social backgrounds, motivation, gender and ethnicity may affect grades and assessment (Klapp Lekholm \& Cliffordson, 2008; 2009). These researchers suggest that teachers often try to maximise students' grade outcomes to benefit both students and schools (see also Cliffordson, 2004a).

Selghed's 2006 exploration of teachers' conceptions of the grading process in upper secondary schools showed rather disparate ideas about the Swedish assessment system. Selghed concluded that teachers graded similarly to how they did before the assessment reforms of 1994 . Both Swedish and international research point to a shift from pencil-and-paper and single-response tests towards performance-based assessment in science education (e.g. Bell \& 
Cowie, 2001; Jakobsson, Mäkitalo, \& Säljö, 2009; James \& Pedder, 2006; Treagust, Jacobowitz, Gallagher, \& Parker, 2001). For example, James and Pedder (2006) argued that the integration of formative assessment in science education may improve results and raise achievement standards. Another example is Treagust et al.'s 2001 study that focussed on a broader programme of teaching and assessment by following a physics class in which the teachers successively improved both effectiveness and learning requirements by encouraging students to discuss and develop their ideas and their scientific language. Another example of the shift is research concerning student perceptions of scientific concepts (greenhouse effect and global warming; Jakobsson et al., 2009). The authors found that the students were able to express their knowledge in a more developed manner and use different knowledge forms when they interacted with others and with cultural tools compared to when they were tested by paper-and-pencil tests. The authors further argued that in studies based on constructivist learning theory, students appeared to have many misconceptions regarding concepts, but their performance improved when they were allowed to discuss and interact with others.

\section{Assessment in Science Education}

As mentioned, several science education scholars have called for reforms concerning assessment of and for learning (e.g., Corrigan, Dillon, \& Gunstone, 2007; Duschl \& Osborne, 2000; Sampson \& Clark, 2008; Tierney, 2006), arguing that the assumptions underlying current assessment approaches fulfilled outmoded functions. Several studies indicate that assessment procedures that focus on elementary knowledge in science often are biased as they rely disproportionately on a narrow range of skills, such as memorisation (e.g., Gallagher, 2007; Gott \& Duggan, 2002; Osborne \& Hennessy, 2003; Roberts \& Gott, 2006). According to these scholars, paper-and-pencil testing might suffice for science programmes that only are designed to acquire facts on a subject. However, promoting more engaging activities, such as problem solving, argumentation and process skills, will require more demanding assessments. For example, Gallagher (2007) argued that these kinds of practices involve tasks that are student-led, have a societal context and may involve broader skills, such as analytical thinking, communication, critical thinking and problem solving. Such activities may be difficult to simply measure through paper-and-pencil examinations that require epistemological discussions about the subject. Recent research has increasingly focussed on formative processes used by teachers to master learning. Stiggins (2006) argued that assessment in modern societies 'must support the learning of all students so all can succeed at meeting standards' (p. 2). Effective classroom assessment may lead to profound achievement; therefore, it must describe students' current status completely. These arguments are in line with this article's general aim vis-à-vis science assessment processes in the Swedish curriculum. However, Black and Wiliam (2003) asserted that the development of formative assessment depends on new practices and assessment tools. They additionally stressed that research about these issues has to include "the perceptions and beliefs of teachers about learning, about the "abilities" and prospects of their students, and about their roles as assessors' (Black \& Wiliam, 1998, p. 51).

\section{Summative and Formative Assessment}

Findings related to the limits of traditional educational assessments (e.g., Elwood, 2006; 
Pellegrino, Chudowsky, \& Glaser, 2001), as well as the increasing amount of evidence over the past decade on the pedagogic potential of formative assessment (e.g., Bennett, 2011; Black \& Wiliam, 2009; Poehner \& Lantolf, 2005; Lundahl, 2011), have increased the public demand for school science reforms. However, according to Black and Wiliam (2003), the terms formative and summative did not apply to the assessments themselves, but rather to the functions they served. They argued that assessment development requires new methods and items that align formative and summative work. This implies that teachers' formative work would not be undermined by summative pressures because of accountability. In comparison, summative requirements might be better served by taking full advantage of improvements in teachers' assessment work. Bennett (2011) defined formative assessment as 'a process used by teachers and students during instruction that provides feedback to adjust ongoing teaching and learning to improve students' achievement of intended instructional outcomes'. He simplifies his statement as follows: 'as long as the results are used to change instruction, any instruments may be used formatively, regardless of its originally intended purpose' (ibid. p. 6).

Newton (2007) asserted that assessment for formative purposes has different accountability characteristics that fundamentally differ from summative assessments. For example, one important aspect of formative assessment is the dialectical relationship between teacher-peer-learner, which can be contextualised as consisting of five 'key strategies' (Black \& Wiliam, 2009, p. 8).

Further, as the responsibility for learning falls on both teachers and learners, peer- and self-assessment is emphasised. However, these forms of assessment seem to be controversial. According to Wiliam (2000), self-assessment opponents often deny student objectivity, although their assertion applies primarily to summative assessment. In other words, accuracy in formative assessment above all is an issue of secondary significance, as the focus is on whether self-assessment can enhance the learning process. According to the authors, other formative features focus on the assessment agent. Traditionally it is the teacher who collects the evidence of learning and decides. However, formative assessment also includes peers and individual learners in the making of such decisions. In this respect, teachers consider students as important instructional resources.

\section{Theoretical Foundations of Learning and Assessment in Research}

In a classic article, Gipps (1994) discussed problems identified with most traditional assessment models, namely: decomposability and decontextualisation. Decomposability often assumes it is possible to divide complex competency learning into smaller parts, which in turn can be assessed through individual stimulus-response connections (Gipps, 1994). Gipps further argued that assessing separate skills may foster teaching practices where learning can be seen as linear and sequential, and where complex understanding occurs only when the basic constraint on learning is mastered. In decontextualisation, 'each component of a complex skill is fixed, and will take the same form no matter where it is used' (Resnick \& Resnick, 1992, p. 43). However, according to the authors, teachers cannot teach a skill component in one setting and expect it to be automatically applicable and assessable in another. In addition, Gipps (1994) argued that situations of 'scaffolding' in learning processes, offered by people who may be more competent, 
may be extended to assessment in situ. To circumvent these issues, Brookhart (2011) suggested that assessment may involve formative approaches, that is, to use assessments based on language, dialogues and collaborative developmental methodologies (Brookhart, 2011; Ash et al., 2007; Poehner, 2011; Poehner \& Lantolf, 2005). These studies view learning and assessment as a productively attached process where the individuals are engaged interactively.

\section{The Concepts of Knowledge and Assessment From a Swedish Perspective}

Teachers' assessment practices are of increasing interest to the educational assessment society in connection with the introduction of new curricula in 1994 and a revised version in 2011. The Swedish curriculum incorporates statements to the effect that students' complete performance, including understanding, aptitude for critical thinking skills and confidence in the subject, should be assessed in order to produce a final grade. In addition, when teachers grade their students, they are to take into account '...all information about students' knowledge in relation to the demands in the syllabus including such knowledge the students acquire by different ways, to make a comprehensive assessment of the students' knowledge during the whole course' (Swedish Ministry of Education, 1994, p. 35). In many respects, this is a major difference from the earlier, centrally controlled system (Lgy, 1970; SKOLFS, 1992, p. 6, 24), in which the total annual grades were nationally balanced in accordance with the normal distribution; the grades in different geographic areas were designated guided by results from annual, centralised, national tests (e.g. Cliffordsson, 2008).

Regarding knowledge and learning, the national curriculum (Skolverket, 2013) stipulates:

The school's task of imparting knowledge presupposes an active discussion about concepts of knowledge, about what knowledge is important today, what will be important in the future, and also about how learning and the acquisition of knowledge take place. (p. 6).

Most of the character of the national curriculum of 1994 is confirmed in the newly revised curriculum from 2011 (SOU, 2008, p. 27). For example, the revised curriculum for the Swedish upper secondary school (Skolverket, 2013) states:

The national school system is based on democratic foundations. The Education Act (2010, p. 800) stipulates that education in the school system aims at students acquiring and developing knowledge and values. It should promote the development and learning of students, and a lifelong desire to learn (Skolverket, 2013, p. 4).

The all-round development of students, scientific ways of thinking and the ability to think critically are also stipulated as follows:

Students should develop their ability to think critically, examine facts and relationships, and appreciate the consequences of different alternatives. By these means students will come closer to scientific ways of thinking and working (Skolverket, 2013, p. 5). 
Regarding assessment, the curriculum does not stipulate directly the kind of assessment teachers should practice but leaves the teachers the possibility of working with formative characteristics of assessment.

\subsection{What types of knowledge and skills/competencies does Swedish Science Education require?}

Besides facts and understanding about the chosen knowledge area the programme of natural science involves:

... the subjects biology, physics and chemistry together with the subject of mathematics are the core of the Natural Science Programme. (...) The education should develop students' knowledge about context in nature, about the conditions for life, about physical phenomena and events, and about chemical processes. (...). The education should stimulate students' curiosity and creativity, and their ability to think analytically. Students should develop a scientific approach.

Regarding critical thinking the Swedish Science Education requires:

Ability to think critically, reason logically, solve problems, and make systematic observations. Students should be given the opportunity to develop the ability to distinguish between statements based on scientific and non-scientific grounds. (...).

Regarding sociocultural issues for the development of society the Swedish Science Education requires:

The education should contain a perspective from the history of ideas, which means that the ideas and theories of the sciences are studied as parts of a historical process. The education should give an understanding of how science and the development of society both affect and are affected by each other and in particular highlight the role of science in questions concerning sustainable development. Students should also be given the opportunity to take part in ethical discussions of the role of science in society (Skolverket, 2012, p. 228).

\section{The Study and the Research Questions}

The overarching purpose is to explore whether teachers are using practices that comply with the national curricula on the concept of knowledge and student assessment participation. Thus, teachers were asked about their assessment practices in three main areas: a) understanding different qualities of science education knowledge, such as procedural skills, analytical skills and critical thinking, as well as how they assessed those qualities; b) what they considered when grading student learning and c) the way in which students participated in the assessment process.

The current study thus addresses the following research questions:

How do science teachers assess and grade students' knowledge in terms of procedural and analytical skills, familiarity and accumulated experience and aptitude for critical thinking?

What should teachers take into account when grading students? 
How are students involved in the assessment process?

In what situations do teachers assess students and how is it made clear to the students that they are being assessed?

\section{Methods and Analytic Procedures}

The sample in this study was composed of 25 teachers in different communities in southern Sweden who were interviewed about their assessment practices. They were chosen by probability sampling (Robson 2007, p. 261), that is, they were randomly selected and offered to participate in the study. One important criterion was that the teachers should be science teachers in first-, second- and third-course programmes in five different schools and certified to teach chemistry, biology and physics at the upper secondary school level. The school samples are representative of those in southern Sweden responsible for upper secondary science programmes. However, as the study strives to collect qualitative data concerning the teachers' own experiences about assessment and grading processes in upper secondary schools, the aim was not to give a simple and generalisable image concerning all Swedish teachers, and instead was to describe and analyse teachers' own experiences about assessment and grading processes from a self-constructed narrative. According to Saldaña (2013), narratives of this kind communicate a category of knowledge that portrays human experiences in a way where actions and events may contribute positively and negatively to the investigation. Thus, the analysis of the teachers' narratives is considered exploratory and the aim is to create trustworthy data collection close to teachers' experiences and ideas. With this in mind, we argue that qualitative methods are more suited to our approach.

The interviews were carefully prepared and lasted around half an hour, excluding time for self-instruction and preparation (for details, see Silverman, 2010). The interview methods were inspired and structured from the perspective of Qualitative Research Interviews designed by Robson (2007), and conducted as individual face-to-face interviews in the form of open-ended or semi-structured questions. This implies that both the interviewer and interviewees were allowed to clear up misunderstandings and interviewees urged to expand on their responses. The interviews were audiotaped with the consent of the respondents and the teachers were asked about their experience about assessment practices in three main areas (see appendice). The names of the teachers are fictitious, and the five schools in different communities in the south of Sweden are named A to E.

\subsection{Data Analysis}

Our data analysis is based on and inspired by assessment research in the international science education community. In the first phase, we analysed the interviews and found categories and subcategories using two coding cycles in the Verbal Coding Exchange System (Saldaña, 2013).The data was then displayed in matrixes (Miles \& Huberman, 1994) to generate all statements about the responder's own experience of assessing and grading processes. Further, in order to find patterns in the material, we coded the data by gathering similar teacher statements and relationships in small experience clusters. This step constituted the first level of the coding process, with the second level being a development of sub-categories by 
examining the teachers' statements, followed by a revision of the first level. In this phase, we also reorganised and reanalysed the data that was coded during the first cycle method.

Our categorisation and sub-categorisation were inspired by Gott and Duggan (2002) and Osborne and Hennessy (2003) in that their results indicate assessment modes that focus on low-level conceptual knowledge. Osborne and Hennessy (2003) additionally suggested that more engaging science (e.g., problem-solving, argumentation and process skills) will require developing more rigorous assessment practices. Many of these suggestions involve tasks that are student-led and classroom-contextualised, and may involve skills such as analytic thinking and communication and practical observation. In this sense, our categorisation considered the teachers' statements and related them to different kinds of assessment practices in the literature.

Three categories were described in the following: Category number 1 - 'The procedures used by teachers to assess and grade students' learning' - aimed to answer the research question: How do science teachers assess and grade students' knowledge in terms of procedural and analytical skills, familiarity and accumulated experience and aptitude for critical thinking? In this first category, we found three different patterns of teachers' assessment practices, which in turn were arranged into three sub-categories:

Sub-category 1a. Process-focussed assessment

Sub-category 1b. Outcome-focussed assessment

Sub-category 1c. Implicit or inconsistent assessment strategies

In subcategory 1a, the assessment of students' development and their understanding of the subject are in focus. Teachers in this category consider the assessment process as a part of students' learning, with the written test not being the critical or dominating grade feature. The process gives teachers opportunities to discuss the social character and the nature of science.

In sub-category $1 \mathrm{~b}$, the teachers are more concerned with students' learning outcomes and accomplishing the curriculum. The teachers assess outcomes basically by written tests with the quantities of knowledge and curriculum compliance being decisive. The written examination is critical when assigning the final grades. In sub-category $1 \mathrm{c}$, the inconsistency of the assessment is related to the sense that teachers display contradictory assessment and grades strategies. These teachers do not consider the assessment process and the test as critical for final grade assignment.

Category 2, 'What is the most critical factor for teachers when deciding on the final grade?', aims to relate to the research question: What is critical for teachers when grading students? In this category, two main patterns were found and identified with the following sub-categories:

Sub-category 2a. Alternative assessment methods

Sub-category $2 \mathrm{~b}$. Traditional assessment methods

'Alternative method' refers to assessments that use examination methods not exclusively for the purposes of grading and often set aside unilateral paper-and-pencil examinations. The 
teachers' assessment in this group is complex and includes different types and levels of student knowledge and skills. Teachers use several methodologies for assessment, such as portfolios, argumentation, dialogues or other assessment methods used for learning. With 'traditional assessment methods', we refer to assessment and grading practices mainly based on paper-and-pencil examinations. In this group, teachers exclude other types of assessment methods.

Category 3, Student participation in the assessment process, is related to the research questions about students' involvement in the assessment process and in what kind of situations teachers assess students, as well as how is it made explicit to them that they are being assessed. In this category, four different patterns were identified; accordingly, two sub-categories were built:

Sub-category 3a: Teachers assert that assessment is their responsibility. Students do not participate.

Sub-category 3b: Teachers have positive insights into students' participation in the assessment process.

\section{Results}

\subsection{The Procedures Used by Teachers to Assess and Grade Students'Learning}

The findings from our study are presented in this section, enlarging on each of the three major categories with associated sub-categories summarised above, while giving examples of teachers' statements in every category based on the interviews. The first category concerns The procedures used by teachers to assess and grade students' learning and relates to the research question about how the teachers assess and grade students in terms of procedural and analytical skills, familiarity and accumulated experience and aptitude for critical thinking. The three general patterns of procedures that were found in the analysis are described in the following three sub-categories.

\subsubsection{Sub-Category 1a. Process-Focussed Assessment}

Only two of the 25 teachers met the criteria for this sub-category. Their assessment methods mainly focus on students' learning and development processes. According to these teachers, assessment is complex, demands to be systematic and achieves its aims by a diversity of approaches. Students' performances are often assessed by evaluating their portfolios and their development and use of scientific language. Students' experimental work, argumentation skills and collaborative performance constitute important parts of the assessment process. One of the teachers addressed the topic as follows:

When they feel [...] when the students are not afraid to come into the laboratory session anymore, but they feel delight and excitement: when they want to begin the work; when they discuss with each other and with me about what chemistry is about, what happens and why; when they observe a chemical reaction; when the students feel that they have developed skills and knowledge [...] they master and manage the chemistry talk! And then [...] I know that they are ready [for the] next step. (Jens). 
This statement may suggest that the teacher has created a kind of interactive tool to assess students' knowledge. The teacher pays attention to the emotional engagement of students in their learning processes (Järvelä, 2011), and claims that the students 'are not afraid to come into the laboratory session anymore, but they feel delight and excitement'. In this respect, this part of the assessment seems to be spontaneous and to consider moments of contingency in the process of learning. Accordingly, the teacher notes the students' impact on his teaching. He further clarifies his ideas about assessment processes thusly:

I assess the students all the time, in the classroom, in the experimental session, and I write every assessment moment in my notebook that students have possibility to discuss with me. Students also have portfolios that I evaluate constantly. All this assessment is considered in the final grades. (Jens).

\subsubsection{Sub-Category 1b. Outcome-Focussed Assessment}

The majority (18) of the respondents were evaluated to meet the criteria in the sub-category of outcome-focussed assessment. The teachers claimed that written tests do not constitute the only foundation to assess students' development and understanding of the subject content. However, they described written tests as the most important and decisive element for grading. Teacher assessment is above all focussed on students' outcomes; explicit aims in the curriculum and the grading processes exclusively depend on written documents and measurements of knowledge. Procedural skills such as those demonstrated during experimental work are not an important factor for grading students.

One teacher in this category was asked about assessing student understanding in physics:

I don't assess classroom situations at all, I don't do it. It is what they do in the written test which counts. (Mathew).

Another teacher was also asked about student understanding and confidence in the subject:

The written test is the most important criterion for grading students. We try to define different tasks, both easy and difficult ones, so that the students can show if they are developing an understanding, skills and confidence. [...]. You can see how far the students have developed by such a discussion, how they're reasoning, if they're right or wrong. This is what gives me insight into their knowledge, understanding, confidence and all of those things. (Regina).

This teacher uses different tools, such as laboratory reports, homework tasks and language skills, as sources for the assessment process; however, these activities do not seem to be given any weight in the total assessment that leads to grades. In this context, she said the following:

Then you can look at the laboratory reports [...], the lessons and all other activities [...]. But you can't raise the grade because of the laboratory reports or something else (...). You cannot do it. It is still knowledge, both in width and depth, which is crucial when grading the students. (Regina). 
Another teacher answered a question about assessing critical thinking in physics as follows:

In physics? [5] Yes [...] they [...] they [...] I don't know, but they are very quick to learn the application of models by using the formulas, which are simplifications of reality in the world [9]. The simplification always matches reality perfectly. Physics is not the same as in social science. There you must call in [to] question [...]. Here, in physics, we are working with models that are tested [...]. In physics nothing needs to be criticised. (Michael).

Only two teachers expressed explicit aims for students needing critical thinking in science. One of these was a biology teacher that endorsed critical aptitude as relevant during discussions on ethical issues of genetic studies. However, the two teachers did not report how they assessed these skills; instead, the teachers expressed the following:

We used to construct different levels of knowledge in the test and in this way we measure all of this... confidence, familiarity and understanding. (Robert).

It is the test that decide all of this, confidence, analysis qualities of knowledge and so on. (Maurice).

\subsubsection{Sub-Category 1c. Implicit or Inconsistent Assessment Strategies}

About one-fifth of the teachers' assessment and grading processes were characterised by implicit or inconsistent strategies. In addition, some of these teachers expressed an uncertainty or even a contradictory view about assessment. One example of this was the following:

There is so much different information about this [what to assess] [...] there is a vast amount of information to base assessments on, that I do not feel insecure when I assign grades. (Jon).

However, when he was asked about the most decisive factor in grading, he replied with a contradictory statement:

It is the written test which is the most critical in assigning grades. I do not assess the student at all in classroom situations, I do not... It is how they perform in the written test which accounts for their final grade. (Jon).

\subsection{The Most Critical Factor for Teachers to Take Into Account for the Final Grade}

The second category relates to what teachers take into account when grading students. In this category, two main patterns of practices were found and identified with two sub-categories:

\subsubsection{Sub Category 2a. Teachers Use Alternative Assessment Methods}

Alternative assessment methods are those that shift away from pencil-and-paper and single-response tests. These could, for example, be performance-based assessments, assessments of communicative skills and evaluation of students' familiarity with the subject through dialogues. In addition, the teachers in this category strive to assess students' performance using several different tools. The written test seems not to be the only critical 
tool for assessment and grading. Only few teachers (2) were found in this sub-category. One of the teachers expressed the most critical factor in chemistry by stating the following:

The most critical factor is that they can communicate chemistry to me and to each other. (Jens).

Another teacher answered the same question as follows:

What is critical to me is that students mastered the scientific language. It is only by mastering the language of science [that] students can talk about new terms, new knowledge, this is important when assessing students. They must discuss and communicate with the others. (Jackeline).

9.2.2 Sub-Category 2b. Teachers that Use Traditional Assessment Methods, that is, Written Examinations

Nearly all of the teachers (23) made statements that indicated that they especially used traditional assessments methods and that the results from written tests constituted the main tool in the grading process. Mathew expressed the most critical grading factor as the following:

Grading a student simply means checking how they performed in four or five written tests during the term. It is the essential thing about it. The written test is very important for the final grade. (Mathew).

Another example is the physics teacher, Joan:

The most important [factor] for assessment and grading is the test. (Joan).

\subsection{How Do Students Participate in the Assessment Process?}

The third category is connected to students' involvement in the assessment process. Additionally this category aims to describe in what kind of situations the teachers assess students and how it is made clear to students that teachers are assessing them. In the analytic phase, we found two explicit patterns of students' participation that we present in the following sub-categories. The categories were built on the teachers' statements and depended on two criteria: a) teachers' ideas about permitting student participation in the assessment process; and b) teachers' statements about students' awareness of situations when teachers were assessing them.

\subsubsection{Sub Category 3a: Teachers Assert that Assessment is Their Task}

A majority of the teachers (20) expressed statements that fell into this category. In general, the teachers expressed that they listen to their students' opinions about different kinds of assessment activities and that they may have opinions about the grading situation at the end of term when they receive their final grades. However, there were no statements in this category that indicated any pervading student involvement during the assessment phase. Some examples of statements in this category were the biology teacher Joachim and the chemistry teacher Charles: 
They [students] are not involved in the assessment process at all [...]. It is me who should possess the knowledge [...] it is me who knows what it is the true, the right things [...] it is me who is the assessor! (Joachim).

They do not assess each other or themselves or such... I do not do anything like that. I am the teacher, I am the assessor [...]. Students' duty is to perform. (Charles).

Another teacher was asked in what ways the students are involved in the assessment and grading processes:

No, $[\ldots]$ they do not participate in the assessment process. They cannot do it, as they are not (...), they try to influence when we discuss grading. (...). Most students accept their grades because they have got the grades they expect, but there are some students who try to influence me as they need higher grades in order to be admitted to the physician education programme. Can I get a higher grade, they say? No, I say! (Regina).

The teacher's statement may suggest that Regina does not separate between the concepts and the process of assessment and grading. She stated specifically:

they do not participate in the assessment process. They cannot do it, as they are not (...), but they try to influence when we discuss grading.

9.3.2 Sub Category 3b: Teachers Have Insights Into Students' Participation in the Assessment Process and They are Positively Open to Alternative Assessment Practices

Only three teachers expressed that they allowed students to participate in assessment. In addition, these teachers also give students self-assessment activities or adopt alternative assessment methodologies (for example, portfolios). The teachers expressed curiosity and positive ideas about alternative assessment methods that involve students. One example is the chemistry teacher, Johanna:

Oh yes, I think that we teachers should work more to improve this (...), sometimes I ask students to make self-assessment in the final of the term, but sadly this practice does not lead to anything. (Johanna).

\subsection{Teacher Comments About Students'Awareness About Assessment Processes}

In order to understand whether students participated in some way in the assessment process, the teacher was asked about students' knowledge of the precise moment they were assessed.

I am not sure if they know, I assess them automatically. (Johnny).

Another one of the teachers addressed the issue more indirectly. She was concerned about students' silence in the classroom and encouraged them to take part in discussions:

Often they are too conscious about assessment. It makes it difficult for them to participate in talking situations during the lessons. I usually encourage students to participate; they refuse to talk [...]. Nobody wants to talk; very often, they observe each other, specially my high achievers; they don't want to say anything. (Brigitte). 
This quotation reveals a possible contradiction between the teacher's assessment for learning purposes and assessment for summative or grading purposes. The teacher is engaged in students' learning, but she probably assesses them by evaluating the answers from discussions. In this situation, the teacher's effort to encourage students to talk does not lead to participation; on the contrary, the students become silent. However, more research is needed about what assessment situations may hinder development.

\section{Discussion}

A summary of results indicates that most of the participating teachers in this study seem to work with rather traditional assessment and grading strategies and methods. Furthermore, analyses suggest that these are often associated with a view of knowledge that is mainly related to a memorisation of subject content and assessed in summative approaches. In addition, the results suggest that summative paper-and-pencil tests are the dominating instrument for the purpose of grading, and that assessment of students' knowledge is principally considered the teacher's task. The students do not participate in the assessment process and only have possibilities to know the result of the assessment made by teachers. In other words, the results of this study imply an explicit distinction between statements from upper secondary science teachers' assessment and grading practices and the Swedish national curriculum that stipulates students' participation in the assessment process. An example is that a vast majority of the teachers meet the criteria in the sub-category of outcome-focussed assessment. The teachers claim that written tests do not constitute the only foundation to assess student understanding of the subject content. However, they describe written tests as the most decisive element for grading. Analyses also indicate that only few teachers use performance-based assessments of communicative skills and evaluation of students' familiarity with the subject through dialogues and development of science vocabulary.

International assessment research (e.g., Brookhart, 2004; 2011; DeLuka \& Klinger, 2010) stresses strategies that focus students' learning and develop their knowledge of the subject. The comments in this study generally speak for themselves, but the various findings in terms of prevalence or level of consensus show that after 20 years of changes in the national curriculum, teachers continue working with traditional assessment practices in the science classroom. We consider that methodologies used to assess the character of knowledge through mainly memorising for examinations may exclude students from articulating their thoughts and discussing scientific and societal issues. As a result, there is a risk that the development of students' critical thinking as well as more sophisticated skills such as curiosity, creativity and ability to think analytically, which the national curriculum stipulates, may be adversely affected (e.g., Corrigan et al., 2007; Duschl \& Osborne, 2000; Sampson \& Clark, 2008; Tierney, 2006). Additionally, Duschl and Osborne (2000) argued that students may not engage in more advanced kinds of science because the type of knowledge the teacher is assessing simply does not demand it. Poehner (2011) asserted that students might be afraid to express their thoughts or hypotheses if they feel that an incorrect answer could adversely affect their grades, or if they ask a question that exposes any lack of knowledge.

One of the teachers tries to solve the problem through allowing students to make mistakes 
when discussing scientific issues and to create assessment-free moments. However, the consensus among the teachers in this study as regards assessment and grading may impact students' development of the skills that the science curriculum requires. The teachers' assessment strategies and methods seem to restrict opportunities for discussing issues concerning the role of science in society and other specific competences. The assessment environment becomes characterised by the written test culture which seems to have a decisive influence on how to organise the subject content and what knowledge forms to emphasise.

Black and Wiliam (2009) argued that if teachers focus merely on the written test, students adapt to this environment and also focus on the written test and the complex qualities of knowledge risk being disregarded. However, increased teacher awareness about the assessment environment may contribute to a better understanding of these issues and their impact on student learning. According to Brookhart $(2004 ; 2011)$, teachers need support as well as explicit tools to develop as assessors and in order to implement the curriculum. An effective integration of formative and summative assessment is needed to promote students' learning, and to activate them as owners of their own learning processes (Brookhart, 2011).

\section{Conclusion}

Teachers continue to use traditional learning and assessment strategies in spite of the changes in the Swedish curriculum; we suggest that one reason for this may be that teachers encounter difficulties in benefitting from the research on educational assessment; further research is needed to explore this claim. Regarding the assessment environment, and following the ideas of Brookhart (2004; 2011), teachers need to create formative assessment environments and need support and instruction in doing this; research in this field has yet to be conducted.

\section{Appendix: Symbols in Transcript Excerpts}

[...] Denotes micro-pause.

[7] Denotes 7-second pause.

Underlining denotes that the word is accented or emphatic.

! Exclamation mark denotes stress or animated tone.

\section{References}

Alkharusi, H. (2008). Effects of classroom assessment practices on students' achievement goals. Educational Assessment, 13, 243-266.

Andersson, P. (2000). Att studera och bli bedömd. Empiriska och teoretiska perspektiv på gymnasie- och vuxenstuderandes sätt att erfara utbildning och bedömningar. Filosofiska fakulteten Linköping universitet No 68. [To study and to be assessed. Empirical and theoretical perspective in upper-secondary and adult school ways of experiencing education and assessments. Linköping Studies in Education and Psychology No 68].

Ash, D., Crain, R., Brandt, C., Loomis, M., Wheaton, M., \& Bennett, C. (2007). Talk, tools, and tensions: Observing biological talk over time. International Journal of Science Education, 
29(12), 1581-1602. http://dx.doi.orrg/10.1080/09500690701494118

Bell, B., \& Cowie, B. (2001). The characteristics of formative assessment in science education. Science Education, 85(5), 536-553. http://dx.doi.orrg/10.1002/sce.1022

Bennett, R. E. (2011). Formative assessment: A critical review. Assessment in Education: Principles, Policy \& Practice, 16(3), 269-290. http://dx.doi.orrg/10.1080/0969594X.2010. 513678.

Black, P., \& Wiliam, D. (2003). 'In praise of educational research': Formative assessment. British Educational Research Journal, 29(5), 623-38.

Black, P., \& Wiliam, D. (1998). Assessment and classroom learning. Assessment in Education: Principles, Policy \& Practice, 5(1), 7-68. http://dx.doi.orrg/10.1080/0969595980050102

Black, P., \& Wiliam, D. (2009). Developing a theory of formative assessment. Educational Assessment, Evaluation and Accountability, 21(1), 5-31.

Brookhart, S. M. (1994). Teachers' grading: Practice and theory. Applied Measurement in Education, 7(4), 279-301.

Brookhart, S. M. (1997). A theoretical framework for the role of classroom assessment in motivating student effort and achievement. Applied Measurement in Education, 10, 161-80.

Brookhart, S. M. (2004). Classroom assessment: Tensions and intersections in theory and practice. Teachers College Record, 106, 429-458.

Brookhart, S. M. (2011). Educational assessment knowledge and skills for teachers. Educational Measurement: Issues and Practice, 30(1), 3-12.

Brookhart, S. M., \& Bronowicz, D. L. (2003). 'I don't like writing. It makes my fingers hurt': Students talk about their classroom assessment. Assessment in Education: Principles, Policy \& Practice, 10, 221-242.

Brown, G. T. L. (2004). Teachers' conceptions on assessment: Implications for policy and professional development. Assessment in Education, 11(3), 301-318.

Brown, G. T. L., \& Hirschfeld, G. H. F. (2008). Students' conceptions of assessment: Links to outcomes. Assessment in Education: Principles, Policy \& Practice, 15(1), 3-17.

Cizek, G., Fitzgerald, S., \& Rachor, R. (1995/1996). Teachers' assessment practices: Preparation, isolation, and the kitchen sink. Educational Assessment, 3(2), 159-179.

Cliffordsson, C. (2008). Differential prediction of study success across academic programs in the Swedish context: The validity of grades and tests as selection instruments for higher education. Educational Assessment, 13, 56-75.

Corrigan, D., Dillon, J., \& Gunstone, R. (2007). The re-emergence of values in science education. SENSE Publishers.

DeLuka, C., \& Klinger, D. A. (2010). Assessment literacy development: Identifying gaps in 
teacher candidates' learning. Assessment in Education: Principles, Policy \& Practice, 17(4), 419-438.

Duschl, R. A., \& Osborne, J. (2000). Supporting and promoting argumentation discourse in science education. Studies in Science Education, 38(2002), 39-72. http://dx.doi.orrg/10.1080/ 03057260208560187.

Elwood, J. (2006). Formative assessment: Possibilities, boundaries and limitations. Assessment in Education, 13(2), 215-232.

Gallagher, J. J. (2007). Teaching science for understanding - A practical guide for middle and high school teachers. Upper Saddle River, NJ: Pearson Merrill Prentice Hall.

Gipps, C. (1994). Beyond testing - Toward a theory of educational assessment. London: The Falmer Press.

Gott, R., \& Duggan, S. (2002). Problems with the assessment of performance in practical science: Which way now? Cambridge Journal of Education, 32(2), 183-201. http://dx.doi.orrg/10.1080/03057640220147540.

Harlen, W., \& Crick, R. D. (2003). Testing and motivation for learning. Assessment in Education, 10(2), 169-207.

Howley, M. D., Howley, A., Henning, J. E., Gillam, M. B., \& Weade, G. (2013). Intersecting domains of assessment knowledge: School typologies based on interviews with secondary teachers. Educational Assessment, 18, 26-48.

Jakobsson, A., Mäkitalo, Å., \& Säljö, R. (2009). Conceptions of knowledge in research on students' understanding of the greenhouse effect: Methodological positions and their consequences for representations of knowing. Science Education, 93(6), 978-995. http://dx.doi.orrg/10.1002/sce.20341.

James, M., \& Pedder, D. (2006). Beyond method: Assessment and learning practices and values. The Curriculum Journal, 17(2), 109-138.

Järvelä, S. (ed.) (2011). Social and emotional aspects of learning. Oxford, UK: Elsevier Academic Press.

Johnston, P. H., Afflerbach, P., \& Weiss, P. B. (1993). Teachers' assessment of the teaching and learning of literacy. Educational Assessment, 1(2), 91-17.

Klapp Lekholm, A., \& Cliffordson, C. (2008). Discrepancies between school grades and test scores at individual and school level: Effects of gender and family background. Educational Research and Evaluation, 14(2), 181-199.

Klapp Lekholm, A., \& Cliffordson, C. (2009). Effects of student characteristics on grades in compulsory school. Educational Research and Evaluation: An International Journal on Theory and Practice, 15(1), 1-23.

Lgy (1970). 70 Läroplaner for gymnasieskola [Curriculum 1970 for Upper Secondary 
School].

Martínez, J. F., Stecher, B., \& Borko, H. (2009). Classroom assessment practices, teacher judgments, and student achievement in mathematics: Evidence from the ECLS. Educational Assessment, 14, 78-102.

McMillan, J. H., \& Nash, S. (2000). Teachers' classroom assessment and grading practices. Decision making. Paper presented at the Annual Meeting of the National Council on Measurement in Education, New Orleans, LA.

McMillan, J. H., Myran, S., \& Workman, D. (2002). Elementary teachers' classroom assessment and grading practices. The Journal of Educational Research, 95(4), 203-213.

Miles, M. B., \& Huberman, A. M. (1994). An expanded sourcebook. Qualitative data analysis (2nd ed.). Oaks California, SAGE Publications.

Newton, P. E. (2007). Clarifying the purposes of educational assessment. Assessment in Education, 14(2), 149-170.

Osborne, J., \& Hennessy, S. (2003). Literature review. In Science education and the role of ICT: Promise, problems and future directions. London: Futurelab Series. Report 6.

Pellegrino, J. W., Chudowsky, N., \& Glaser, R. (2001). Knowing what students know: The science and design of educational assessment. The National Academy of Sciences, USA.

Poehner, M. E. (2011). Dynamic assessment: Fairness through the prism of mediation. Assessment in Education: Principles, Policy \& Practice, 18(2), 99-112.

Poehner, M. E., \& Lantolf, J. P. (2005). Dynamic assessment in the language classroom. Language Teaching Research, 9(3), 233-265.

Resnick, L. B. and Resnick, D. P. (1992). "Assessing the thinking curriculum. New tools for educational reform", in B. Gifford, \& M. O’Connor (Eds). Changing assessment: Alternative views of Aptitude, Achievement and Instruction, London, Kluwer Academic publishers.

Robson, C. (2007). Real world research. A resource for social scientists and practitioners researchers. Second Edition. Oxford, UK: Blackwell Publishing.

Saldaña, J. (2013). The coding manual for qualitative researchers. Second Edition. Los Angeles: Sage.

Sampson, V., \& Clark, D. B. (2008). Assessment of the ways students generate arguments in science education: Current perspectives and recommendations for future directions. Science Education, 92(3), 447-472. http://dx.doi.orrg/10.1002/sce.20276

Selghed, B. (2006). Betygen i skolan - kunskapsyn, bedömningsprinciper och lärarpraxis [Grades in the school - Knowledge views, assessment principles and teachers' practices]. Stockholm: Repro 8 AB Nacka.

Silverman, C. (2010). Doing qualitative research, a practical handbook. Third Edition. London: SAGE. 
SKOLFS. (1992). 1992:4 Skolverketsförfattsamling [The Swedish National Agency for Education].

Skolverket (2012). Curriculum for the upper secondary school. Natural Science Programme, 2012-10-31 [The Swedish National Agency for Education]. Retrieved from www.skolverket.se

Skolverket (2013). Curriculum for the upper secondary school [The Swedish National Agency for Education, Stockholm]. Retrieved from www.skolverket.se

SOU (2008). Statens Offentliga Utredningar 2008:27. [The Swedish Government Official Government Report].

Stiggins, R. (2006). Assessment for learning: A key to motivation and achievement. Edge: The Latest Information for the Education.

Svensk författningssamling. (2010). SFS nr: 2010:800 Utbildningsdepartementet, 2010-06-23 [The Swedish Ministry of Education SFS nr: 2010:800].

Swedish Ministry of Education. (1994). Läroplaner för det obligatoriska skolväsendet och de frivilliga skolformerna [The Swedish Curriculum, 1994].

Tierney, R. D. (2006). Changing practices: Influences on classroom assessment. Assessment in Education, 13(3), 239-264.

Treagust, D. F., Jacobowitz, R., Gallagher, J. L., \& Parker, J. (2001). Using assessment as a guide in teaching for understanding: A case study of a middle school science class learning about sound. Science Education, 85(2), 137-157. http://dx.doi.orrg/10.1002/1098-237X (200103)85:2<137::AID-SCE30>3.0.CO;2-B.

Wiliam, D. (2000). Formative assessment in mathematics. Part 3: The learner's role. Equals: Mathematics and Special Educational Needs, 6(1), 19-22.

\section{Copyright Disclaimer}

Copyright reserved by the author(s).

This article is an open-access article distributed under the terms and conditions of the Creative Commons Attribution license (http://creativecommons.org/licenses/by/3.0/). 